\title{
Market Participation and Farm Profitability: The Case of Northern Ghana
}

\author{
Agness Mzyece ${ }^{1}$ \\ ${ }^{1}$ Department of Agricultural Economics, Kansas State University, Manhattan, Kansas, USA \\ Correspondence: Agness Mzyece, Department of Agricultural Economics, Kansas State University, 1603 Old \\ Claflin Pl, Manhattan, KS 66506, USA. Tel: 1-319-385-6340. E-mail: amzyece@ksu.edu
}

Received: December 8, 2020 Accepted: January 15, $2021 \quad$ Online Published: January 23, 2021

doi:10.5539/sar.v10n2p1

URL: https://doi.org/10.5539/sar.v10n2p1

\begin{abstract}
This study examines the effect of quantity sold (sales volume) on profitability of market participating smallholder farmers in northern Ghana. Market participation has been shown to be important for increasing incomes and improving production efficiency for farm households but still remains low in SSA. While agribusiness and development experts generally advocate for more intensive market participation, it is not clear if selling more results in more profits for smallholder farmers in remote markets that are prone to exorbitant transaction costs. The data used in this study is from the APS survey conducted in 2013 and 2014 in Northern Ghana which had a sample size of 527. The study is based on the theory of profit maximization, in which separability is inferred from observed market participation. OLS regression is used for empirical estimation after rejecting the hypothesis of endogeneity in the model. Mean gross margin/ $\mathrm{kg}$ across four groups of farmers ranked by quantity sold is also statistically examined. The results confirm the existence of economies of scale and also show that different crops have different effects on profitability. The results also show that although unambiguously positive, the relationship between quantity sold and profitability may not be linear.
\end{abstract}

Keywords: market participation, quantity sold, profit, Northern Ghana

\section{Introduction}

\subsection{Research Background}

Stimulating smallholder market participation is one way of breaking the rural poor free from their poverty trap (Barrett 2008). Market participation has the potential to contribute towards increasing farm incomes and enabling farming households to improve their production systems (Alene et al., 2008; Jagwe et al., 2010; Omiti et al., 2009). Market participation compels farmers to use more efficient and intensified production systems that yield a larger marketable surplus. Research in Kenya and South Africa has shown that there is a positive relationship between the share of households' agricultural output sold in the market and the level of production efficiency and yields (Barrett, 2008; Omiti et al., 2009). Farmers who sell their produce also access income that they can use to meet other household needs including buying food. For Sub Saharan Africa (SSA), where more than 80 percent of rural households depend on agriculture for their livelihoods (International Fund for Agricultural Development, 2011), market participation is of particular importance for improving the standards of living for rural households. However, for most SSA countries such as Ghana, many smallholder farmers in remote areas opt not to participate in markets due to inadequate access to productive technologies to produce a marketable surplus and due to poor institutions and infrastructure which make it difficult and costly for them to access markets (Barrett, 2008).

In the northern regions of Ghana, the marketed share of farm products and the percentage of farmers who sell their produce tend to be lowest compared to the rest of the country. This is partly due to limited opportunities for intensifying and commercializing agriculture, e.g., poor access to input and output markets (Chamberlin et al., 2007). Since more than $70 \%$ of the economically active population in northern Ghana is engaged in agricultural activities (Ghana Statistical Service, 2012), the low levels of market participation have contributed to generally higher rates of poverty and food insecurity in the region compared to the rest of the country (Chamberlin et al., 2007). More than half of Ghana's population living in extreme poverty lives in the northern regions (Savannah Accelerated Development Authority, 2010). Further, while only 5\% of Ghana's population is considered food insecure, the proportion of residents in the northern part of the country that are food insecure has been estimated 
to be anywhere from double to seven times the national average (Usaid|Ghana, 2011). Although current statistics show that there has been an $11.7 \%$ reduction in people living on less than $\$ 1.25$ a day in northern Ghana between 2012 and 2015 (Zereyesus et al., 2014, 2015), households in northern Ghana still remain more vulnerable than others in the rest of the country and efforts to support them need to continue and increase. In light of the under-performing markets, market participation studies are imperative for the region.

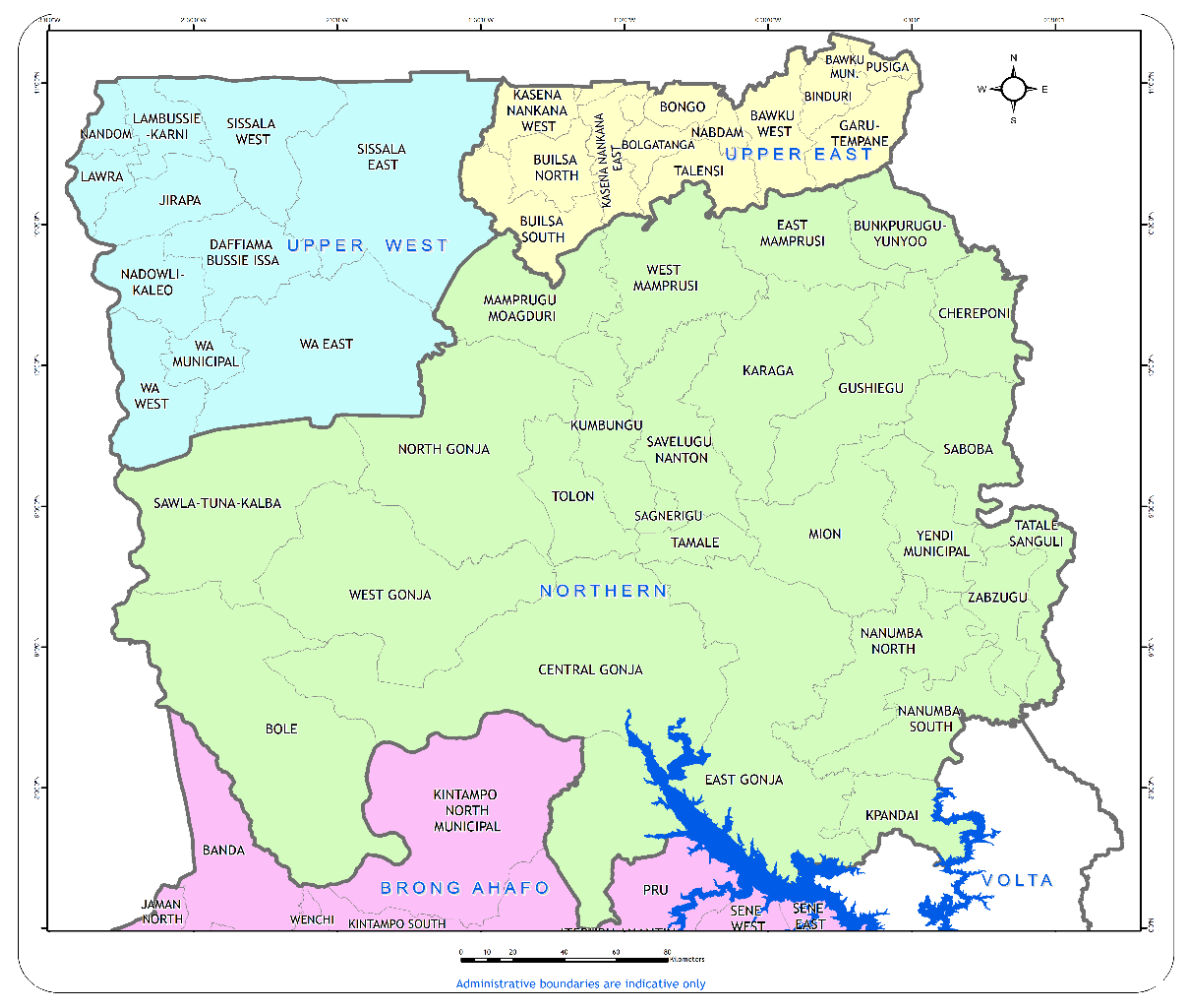

Figure 1. Map of Northern Ghana

\subsection{Research Gap}

Previous research on market participation in northern Ghana has mainly focused on identifying strategies for getting non-market participating farmers to join the market (Mzyece 2016; Amankwah. et al. 2012). Other studies have focused on assessing the technical and institutional constraints to innovation in smallholder small ruminant production and marketing as well as examining the use of mobile phones in reducing transaction costs and enhancing market participation (Zanello, 2012; Zanello et al., 2014). However, evidence on whether it is profitable to sell and particularly if selling more entails higher profits is lacking. Profitability is most likely the major motivating factor for intensive market participation. Efforts to promote market participation without an understanding of profitability may therefore yield uncertain outcomes. If it is unprofitable to sell, for example, farmers who join the market will inevitably opt out with time. Similarly, if it's not necessarily more profitable to sell more, farmers will reduce sales volumes or continue to sell small quantity of produce regardless of efforts to get them to sell them more. Sustainability of market participation is therefore likely tied to profitability since profitability is the incentive for continuing or growing a farming business (Mishra, El-Osta, and Steele 1999; Tey and Brindal 2015; McGrann 2014). This study is a step towards filling the dearth in knowledge on the relationship between profitability and market participation in SSA. The study analyzes the effect of sales volume, among other factors, on the profitability of smallholder market participants. It aims to address the question of whether smallholder farmers who sell more output earn a higher or lower profit than those who sell less. Smallholder farmers are rational agents who will engage in an activity from which they expect a positive return. Strategies to get farmers to participate in the market are therefore likely to be most effective if oriented toward improving farm profitability. The results of this study may therefore help policy makers to align market participation interventions with the goal of increasing farm profitability rather than increasing farm sales for the sake of selling (a clearly unsustainable policy goal).

In this paper, we begin by presenting the underlying theoretical and empirical framework for farm household 
marketing decisions and profitability as well as the data used in the analysis. Thereafter, the results, which include the descriptive statistics and the regression results are presented and discussed. The paper concludes by looking at the implications of the results, particularly for policy.

\section{Methods}

\subsection{Conceptual Framework}

Traditionally, agricultural household modelling has been based on a recursive model, a theoretically consistent microeconomic model in which households are assumed to be price takers making production, consumption and labor supply decisions simultaneously. However, in cases where these assumptions do not hold as is the case when markets fail or are not used by the producer, Singh, Squire, and Strauss (1986) proposed the non-separable household model. The non-separable household model is a variant of the recursive model in which utility and profit-maximization decisions are made jointly. The non-separable household model has been extensively adopted for areas where markets notably fail smallholder farmers in remote areas e.g., in rural SSA (de Janvry, Fafchamps, and Sadoulet 1991; Key, Sadoulet, and Janvry 2000; Barrett 2008; Olwande et al. 2015)

This study analyzes factors affecting profitability assuming that the farm household is a profit maximizing agent. Profit-maximizing behavior is a special case of the non-separability model in which consumption and production decisions are considered separately because prices are determined exogenously in perfect markets (Olwande et al., 2015). In addition, Key, Sadoulet, and Janvry (2000), Carter and Yao (2002) and Vakis et. al (2004) show that in the case where market participation can be observed and used to infer market failure, then market participation can be used to infer separability. In this study, we observe market participation and particularly focus on farmers who participated in the market. Therefore, we consider the separable/ recursive model to be justified. Consistent with Singh, Squire, and Strauss (1986), output consumed is viewed as output which the household sold to themselves. Therefore, in calculating total revenue, the value of output consumed based on local average prices is treated as revenue.

Previous literature has differentiated farm households as being either net sellers, net buyers or autarkic (Singh, Squire, and Strauss 1986, Barrett 2008, De Janvry and Sadoulet 2016). In this study, however, we do not have data on purchases. Therefore, we only consider farm households who sell some amount of their produce as being sellers and those who do not sell anything as being autarkic. Due to data limitations as well, we omit the concept of full income motivated by Becker (1965).

The adapted profit maximization problem for the farm household under the assumption of separability is set as follows. Given that $Q_{i p}$ is the output of an agricultural crop, $C_{i p}$ is the per unit cost of production for the agricultural crop, $Q_{i s}$ is the quantity of the crop sold (which is a function of demographic characteristics, $Z$, production characteristics, $P_{i}$ and market characteristics, $K$ ), and that $C_{i s}$ is the per unit transaction costs associated with selling, each household maximizes gross margin (total revenue minus total variable costs (TVC)) from net sales subject to a production function, where $X_{i}$ is a vector of inputs used in the production of each crop.

$$
\begin{array}{cr}
\operatorname{Max} \pi=\sum_{i=1}^{n} P_{i} Q_{i s}\left(Z, P_{i}, K\right)-\left[\left(Q_{i p} C_{i p}\right)+\left(Q_{i s}\left(Z, P_{i}, K\right) C_{i s}\right)\right] & \text { Objective function } \\
Q_{i}=f\left(X_{i}\right) & \text { Production function } \\
Q_{i}, C_{i}, X_{i}, P_{i} \geq 0 & \text { Non negativity condition }
\end{array}
$$

\subsection{Empirical Model}

An Ordinary Least Square (OLS) regression is used in determining factors affecting gross margin. Although simplistic, this approach of using OLS is prone to endogeneity arising from potential simultaneity. That is, while quantity sold may have an effect on profitability, the interrelations between profit, price, variable costs and quantity sold may result in a reverse effect of profit on quantity sold. The potential simultaneity between quantity sold and profitability may be illustrated in the diagram below, in which the direction of each arrow depicts the potential direction of effect. 


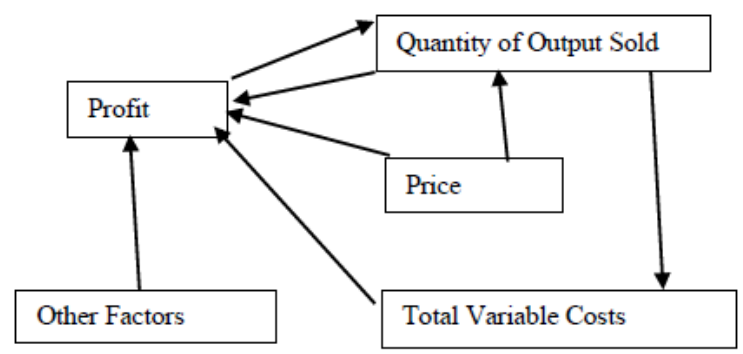

Figure 2. Potential Simultaneity in the Model

If simultaneity/endogeneity is indeed present, we would need to use instrument variable (IV) regression based on a Two-Stage Least Square (2SLS) estimation or an efficient Generalized Method of Moment (GMM). In view of the suspected simultaneity in the model, we first test for endogeneity of the independent variable, quantity sold. The regression-based test rejects the null hypothesis of endogeneity. If we apply IV regression or 2SLS when there is in fact no endogeneity, these methods yield estimators that are consistent but inefficient (Gujarati \& Porter, 2003). Therefore, we use OLS regression in this study. Realizing that the regression-based test for endogeneity relies on the specification of the quantity sold model (equation 4), we still go ahead to run the 2SLS and GMM estimation as robustness checks. The results of the efficient GMM and 2SLS presented in Appendix A are very similar to those of the OLS regression suggesting that quantity sold may indeed be exogenous in this study. We therefore cautiously proceed to use OLS regression for the empirical analysis.

Using OLS models, we run two separate models on the factors affecting Gross margin for all sellers. Based on Mishra (2009), in the main model of inference, we use total gross margin as the dependent variable. In another model, we use gross margin per acre to see how the results change when we control for land size. The OLS model is specified as follows:

$$
G M=\alpha_{0}+\alpha_{1} \text { Age }+\alpha_{2} \text { Gnd }+\alpha_{3} \text { HHsiz }+\alpha_{4} \text { Lit }+\alpha_{5} \text { Fout }+\alpha_{6} \text { Qsold }+\alpha_{6} \text { Buyer }
$$

Where Gnd is gender, HHsiz is household size, Lit is literacy, Fout is farm output, Qsold is quantity sold and Buyer is buyer type. Age, gender, household size and literacy are defined as demographic variables, farm output is defined as a production variable while quantity sold and buyer type are market variables.

\subsection{Data}

The study uses data from the 2013-2014 Agriculture Production Survey (APS) funded by the United States Agency for International Development (USAID). The total sample was 527 farmers across 25 districts in the Zone of Influence of the USAID's Feed the Future Initiative. The sampling method used was a two-stage stratified random sampling approach. Additional data on relevant missing variables was accessed from the baseline Population Based Survey (PBS) conducted in northern Ghana in 2012 and funded by Feed the Future Initiative under USAID|Ghana. The baseline was from a sample size of 4600 drawn through a two-stage probability sampling approach. The households captured under the APS were largely captured under the PBS such that triangulation of missing data from the APS onto the PBS was possible.

Table 1. Summary Statistics on Variables Used in Analysis

\begin{tabular}{llllll}
\hline Variable & Variable Description & Mean & SE & Min & Max \\
\hline Gross Margin & Gross margin in GHS & -13.16 & 392.66 & -790 & 3319.71 \\
Age & Age in years & 46.33 & 14.79 & 20 & 100 \\
Female & 1 if female & 0.08 & 0.28 & 0 & 1 \\
Household size & Number of people living in the household & 10.36 & 5.86 & 2 & 53 \\
Literate & 1 if literate in English or local language & 0.97 & 0.16 & 0 & 1 \\
Yield & Output per acre in KG/acre & 107.40 & 244.57 & 3.70 & 2327.78 \\
Quantity of Maize sold & Quantity of maize sold in KGs & 396.94 & 587.42 & 1.00 & 6000 \\
Quantity of Rice sold & Quantity of rice sold in KGs & 343.24 & 872.19 & 1.68 & 8400 \\
Quantity of Soybean sold & Quantity of soybean sold in KGs & 292.43 & 251.97 & 5 & 1100 \\
Sold to Aggregators & 1 if aggregator is major buyer & 0.15 & 0.35 & 0 & 1 \\
Sold to Processors & 1 if processor is major buyer & 0.01 & 0.10 & 0 & 1 \\
Sold to Consumers & 1 if consumer is major buyer & 0.15 & 0.35 & 0 & 1 \\
Sold to other buyers & 1 if other buyers is major buyer & 0.54 & 0.50 & 0 & 1 \\
\hline
\end{tabular}


${ }^{1}$ GHS is Ghana's currency, Ghana Cede

1USD = 2.68GHS in March, 2013 (Bank of Ghana 2014).

The survey collected detailed information on farmers' production and marketing characteristics. The production data were collected over the entire 2013 cropping season in northern Ghana, from late June to mid-November. The marketing data were collected during follow-up visits in January, February, and March of 2014. The crop production data mainly focused on three crops in northern Ghana: maize, rice, and soybeans. The marketing data included information on quantity sold, type of buyers, and price received for each crop. Based on previous literature, the factors identified as having an effect on profitability in this study are presented in Table 1.

\section{Results}

\subsection{Descriptive Statistics}

The results show that only $47 \%$ of the farmers sold their produce and that, on average, farmers were making a loss of about 13 GHS in the 2013/2014 agricultural season in northern Ghana. The average quantity of maize sold was $396.94 \mathrm{~kg}$, which represents only $7 \%$ of the average total output. The average quantity of rice sold was $343.24 \mathrm{~kg}$ ( $23 \%$ of output) while the average quantity of soybean sold was $292.43 \mathrm{~kg}$ ( $34 \%$ of output). These findings support existing evidence of soybean being a commercial crop and maize being mainly grown for consumption among smallholder farmers in SSA.

The dependent variable in this study is profitability measured using both total gross margin and gross margin per acre. We include the value of produce consumed by the household in calculating revenue and therefore gross margin. However, because the focus of the paper is on profitability from selling, we also examine profitability purely from sales (excluding consumption). The results show that based on total output (sales plus consumption revenue), maize is the least profitable crop with an average total gross margin of -105.47 GHS. However, based purely on sales, maize is the most profitable crop with an average total gross margin of 194.00 GHS. Rice has an average gross margin of -49.25 GHS based on total output, while based on sales alone, it has an average gross margin of 78.60 GHS. Soybean has an average gross margin of 25.83 GHS based on total output and an average gross margin of 91.71 GHS based on sales alone.

The results further show a positive relationship between gross margin and total quantity of output sold in which farmers who sell more output have a higher gross margin per acre. In fact, the results suggest that farmers who sell small quantities of less than about 500kg typically make loses. Figure 3 shows the relationship between gross margin per acre and quantity of maize sold in which the evidence of a positive relationship between gross margin per hectare and quantity sold is supported.

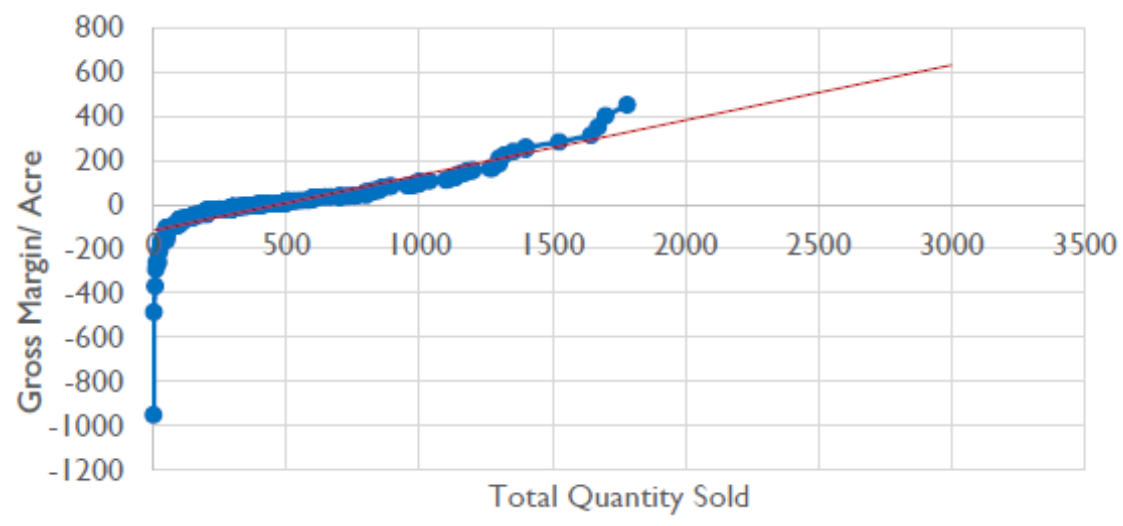

Figure 3. Relationship between Gross Margin/ Acre and Total Quantity Sold

\subsection{Empirical Results}

Table 2 shows the results of the empirical estimation of the effect of quantity sold on gross margin and on gross margin per acre. The results show that the factors that significantly affect total gross margin at $10 \%$ significance level include age, household size, quantity of maize sold, quantity of rice sold, quantity of soybean sold, and selling to aggregators. The results show that older farmers are more profitable than young farmers. That is, a one-year increase in age is associated with a $3.97 \mathrm{GHS}$ increase in total gross margin at $1 \%$ significance level. 
For the gross margin per acre model, age increase gross margin per acre by 4.72 GHS/acre at $10 \%$ significance level. This findings suggests a positive effect of age on profit, and is consistent with findings by Foreman and Livezey (2003) and Mishra and Wilson (2009) who show that farmers become proficient and knowledgeable with experience while young farmers have fewer assets that do not allow them to produce profitably. The results also show that an additional household member reduces total gross margin by 8.94 GHS. This is an unexpected result as one could expect large households to have more household labor supply leading to larger gross margins especially that in calculating gross margin, the opportunity cost of output consumed is treated as part of revenue. Tey and Brindal (2015) also assert that because agriculture is labor intensive, a larger household is more likely to overcome labor constraints and be more profitable. This result could suggest that additional household members contribute disproportionately more to cost of production than to output produced in northern Ghana.

The variable of interest (quantity sold) is disaggregated into quantity of maize sold, quantity of rice sold and quantity of soybean sold to examine how the quantities of the unique crops affect profitability. The results show that as the quantity of soybean, rice and maize sold increases, gross margin also increase. This finding is in line with that of Tackie, Findlay and Baharanyi (1998) who also found that increased sales volume has a positive impact on profitability due to economies of scale for farmers in the United States. Specifically our results show that an additional kilogram of maize sold will significantly increase total gross margin by 0.47 GHS at $1 \%$ significance level, an additional kilogram of soybean sold will significantly increase gross margin by 0.46 GHS at $1 \%$ significance level and an additional kilogram of rice sold will significantly increase gross margin by 0.64 GHS at $1 \%$ significance level and will significantly increase gross margin per hectare by $0.21 \mathrm{GHS} /$ acre at $5 \%$ significance level. An additional unit of rice sold is therefore more profitable than an additional unit of maize sold. This suggests that the type of crop being sold matters in identifying the effect of sales volume on profitability. This result is also in line with findings by Tackie, Findlay, and Baharanyi (1998), who showed that concentrating in the production of high value products increased profitability more compared to concentrating in other crop types.

Table 2. OLS Regression Results

\begin{tabular}{lllll}
\hline & \multicolumn{2}{l}{ Gross Margin $^{2}(\mathrm{n}=302)$} & \multicolumn{2}{l}{ Gross Margin per Acre $^{3}(\mathrm{n}=285)$} \\
\hline Variable & Coefficient & Robust Std Error & Coefficient & Robust Std Error \\
\hline Age & $3.97 * * *$ & 1.35 & $4.72^{*}$ & 2.28 \\
Female & 3.40 & 120.74 & 144.99 & 168.79 \\
Household size & $-8.94 * *$ & 3.52 & 1.21 & 9.51 \\
Literate & 171.54 & 111.31 & 74.90 & 102.89 \\
Farm Output & 0.02 & 0.10 & -0.02 & 0.05 \\
Quantity of Maize sold & $0.47^{* * *}$ & 0.08 & 0.09 & 0.07 \\
Quantity of Rice sold & $0.64^{* * *}$ & 0.05 & $0.21^{* *}$ & 0.08 \\
Quantity of Soybean sold & $0.46^{* * *}$ & 0.10 & -0.14 & 0.30 \\
Sold to Aggregators & $-116.45^{*}$ & 68.08 & 297.99 & 347.08 \\
Sold to Processors & 192.19 & 223.81 & -40.78 & 56.07 \\
Sold to Others & 61.52 & 59.30 & 61.34 & 78.35 \\
_constant & -318.63 & 139.57 & -289.52 & 213.08 \\
\hline
\end{tabular}

Note: Asterisks, $* * *=$ significant at $1 \%, * *=$ significant at $5 \%$ and $*=$ significant at $10 \%$

${ }^{1}$ For Gross margin per acre, the variable used is farm output and not yield

${ }^{2} \mathrm{R}$ - squared $=43.1 \%$

${ }^{3} \mathrm{R}$ - squared $=6.2 \%$

1USD $=2.68$ GHS in March, 2013 (Bank of Ghana 2014).

Furthermore, the results show that the type of buyer to whom a farmer sells their produce may affect their profitability. Selling to aggregators (wholesale-type middlemen) was significantly less profitable compared to selling directly to final consumers. Selling to aggregators was associated with a 116.45 GHS less profit compared to selling to final consumers. This could be because aggregators buy at lower prices compared to consumers (Mzyece, 2016).

To get a clearer picture of how gross margin increases as quantity sold increases, we ranked the households in the sample in ascending order according to the amount of output they sold. Based on this ranking, we created four groups of farmers. The first group of farmers are those who have the lowest $25 \%$ of sales volume among all 
sellers. These are called "group 1". Those selling the second lowest $25 \%$ of sales volume among the seller are called "group 2" and so on and so forth. We then compare the mean gross margin/ kg across these groups and also test if they are statistically different from each other.

Table 3. Gross Margin /Kg Ranked by Quantity Sold

\begin{tabular}{llllc}
\hline & Mean gross margin & Standard Error & \multicolumn{2}{l}{ [95\% Confidence Interval] } \\
\hline Group 1 & -1.61 & 0.96 & -3.49 & 0.27 \\
Group 2 & 0.02 & 0.03 & -0.04 & 0.08 \\
Group 3 & 0.17 & 0.06 & 0.06 & 0.28 \\
Group 4 & 0.10 & 0.02 & 0.07 & 0.13 \\
\hline
\end{tabular}

Ho: Means are statistically same across the four groups (Hotelling T2 $=11.44$, Hotelling F $(3,295)=3.79$, Prob > $\mathrm{F}=0.0108)$

The results show that the mean gross margin/ $\mathrm{kg}$ across the four groups are statistically different from each other at $95 \%$ confidence level and also generally confirm that profits increase as quantity sold increases. More specifically, the results show that the farmers selling the lowest quantities are making loses on average. As quantity sold increases for group 2 and 3, average gross margin/ $\mathrm{kg}$ increases. But interestingly, for group 4 which sells the largest $25 \%$ of output, gross margin/ $\mathrm{kg}$ is lower than that of group 3 . This could imply that the increase in profits as quantity sold increases is not linear. The increase in profits could perhaps be concave in sales volume, initially increasing at an increasing rate, then increasing at a decreasing rate and eventually, possibly decreasing. This could mean that, although we generally advocate for farmers to sell more, there could be optimal levels of quantities that farmers need to sell in order to maximize profits. This is particularly true if the relationship is an inverted $U$ shaped curve. However, further research is required to confirm the type of relationship between profit and quantity sold in northern Ghana and to ascertain the typical profit-maximizing sales volume given farmer characteristics.

\section{Conclusion and Recommendations}

This study was carried out with an objective to determine if selling larger quantities of output leads to higher profits. Profitability is an incentive for new market entrants and existing sellers to continue selling or to sell more. The study focused on northern Ghana which is relatively poorer than the rest of the country partly due to low levels of market. The study is based on the theory of profit maximization and OLS regression was used for estimation. Mean gross margin/ $\mathrm{kg}$ are also compared across four groups ranked by quantity sold. The data used is from the APS survey conducted in 2013 and 2014 funded by USAID which had a sample size of 527.

Results from the OLS regression show that the quantity sold for all three crops, maize rice and soybean had a positive significant impact on profitability. This confirms the existence of potential economies of scales effects to selling maize, rice and soybean even in emergent markets like northern Ghana where transaction costs are still very high. Another finding worth noting is that the magnitude of impact of quantity sold on profit depends on the crop being sold. The comparison of mean gross margin/ $\mathrm{kg}$ across four groups of farmers ranked by quantity sold show that the farmers who had the lowest $25 \%$ of sales volume among the sellers (group 1) made loses. Mean gross margin/ $\mathrm{kg}$ increased as output increased across groups 1,2 to 3 . However, group 4 which sold the largest quantities had a lower mean gross margin/ $\mathrm{kg}$ than group 3, possibly implying diminishing marginal returns or simply a non-linear relationship between quantity sold and profit.

\subsection{Policy Implications}

The results show that different crops have different effects on profitability. An increase in quantity of rice sold, for example, increases profits by 0.64 GHS while quantity of maize sold increases profits by 0.47 GHS. These results therefore reinforce the idea that promoting high value crops may result in higher profitability for farmers. The promotion of high value crops may consequently encourage sustainable market participation. The results also show that selling to aggregators is less profitable compared to selling to consumers. This could imply that while middlemen act as a bridge to final consumer markets for farmers in remote areas, interventions that can ensure profitable and sustainable market participation for farmers should prioritize linking farmers to final consumer markets. This could be achieved by, for example, building rural road infrastructure to major cities.

Market participation literature generally advocates for higher intensities of participation (selling more). However, these results bring to light the possibility of having an optimal amount of sales that a farmer can sell given his specific market conditions. Although still requiring further research, these findings contradict the traditional "blanket" recommendation that selling more always brings higher returns for farmers. 


\subsection{Limitations and Further Research}

Findings from this study show that although the relationship between quantity sold and profit may be positive, it may not be linear. If it is an inverted U-shaped curve, it could imply that there is an optimum quantity to sell. Further research is needed to ascertain this relationship which could certainly have policy implications. Due to data limitations, this study did not account for household purchases. Therefore, households were not categorized as being net sellers or net buyers. Further research can look at how differently profitability is affected by sales volume between the net buyers and net sellers. Finally, this study did not include data on farm assets and off-farm income due to data limitations as well. Farm asset ownership may enable farmers to invest more and therefore make more profit while off-farm income may provide additional income that can be invested on the farm. Further research can include these variables in analyzing factors affecting profitability to see if the results change significantly when these factors are included.

\section{Acknowledgments}

The author would like to acknowledge the United States Agency for International Development (USAID) Feed the Future Initiative for providing the data for this research through the Monitoring Evaluation and Technical Support Services (METSS) program at Kansas State University.

\section{References}

Alene, A. D., Manyong, V. M., Omanya, G., Mignouna, H. D., Bokanga, M., \& Odhiambo, G. (2008). Smallholder market participation under transactions costs: Maize supply and fertilizer demand in Kenya. Food Policy, 33(4), 318-328. https://doi.org/10.1016/j.foodpol.2007.12.001

Amankwah, K., Klerkx, L., Oosting, S. J., Sakyi-Dawson, O., van der Zijpp, A. J., \& Millar, D. (2012). Diagnosing Constraints to Market Participation of Small Ruminant Producers in Northern Ghana: An Innovation Systems Analysis. NJAS- Wageningen Journal of Life Sciences. https://doi.org/10.1016/j.njas.2012.06.002

Barrett, C. B. (2008). Smallholder market participation: Concepts and evidence from eastern and southern Africa. Food Policy, 33(4), 299-317. https://doi.org/10.1016/j.foodpol.2007.10.005

Becker, G. S. (1965). A Theory of the Allocation of Time. The Economic Journal, 75(299), 493-517. https://doi.org/10.2307/2228949

Carter, M. R., \& Yao, Y. (2002). Local Versus Global Separability in Agricultural Household models: The Factor Price Equalization Effect of Land Transfer Rights. American Journal of Agricultural Economics, 84, 702-715. https://doi.org/10.1111/1467-8276.00329

Chamberlin, J., Diao, X., Kolavalli, S., \& Breisinger, C. (2007). Smallholder Agriculture in Ghana. Retrieved from http://pdf.usaid.gov/pdf_docs/Pnad1411.pdf

De Janvry, A., \& Sadoulet, E. (2016). Development Economics: Theory and Practice (First). Routledge. https://doi.org/10.4324/9781315715520

de Janvry, A., Fafchamps, M., \& Sadoulet, E. (1991). Peasant Household Behaviour with Missing Markets: Some Paradoxes Explained. Economic Journal, 101(409), 1400-1417. https://doi.org/10.2307/2234892

Foreman, L. F., \& Livezey, J. S. (2003). Factors Contributing to Financially Successful Southern Rice Farms Factors Contributing to Financially Successful Southern Rice Farms. Southern Agricultural Economics Association Annual Meeting, Mobile, Alabama, 19.

Ghana Statistical Service. (2012). 2010 Population and Housing Census. Ghana Statistical Service, 1-117. https://doi.org/10.1371/journal.pone.0104053

Gujarati, D. N., \& Porter, D. C. (2003). Basic econometrics - Economic series McGraw-Hill international editions: Economic series. In ... Econometrics. p. 1002. https://doi.org/10.2307/2344828

International Fund for Agricultural Development. (2011). Rural Poverty Report.

Jagwe, J., Machethe, C., \& Ouma, E. (2010). Transaction costs and smallholder farmers' participation in banana markets in the Great Lakes Region of Burundi, Rwanda and the Democratic Republic of Congo. African Journal of Agricultural and Resource Economics, 6(1), 302-317.

Key, N., Sadoulet, E., \& Janvry, A. De. (2000). Transactions Costs and Agricultural Household Supply Response. American Journal of Agricultural Economics, 82(2), 245-259. https://doi.org/10.1111/0002-9092.00022

McGrann, J. (2014). Best Measure Of Ranch Sustainability Is Economic Profitability. Retrieved from 
https://www.beefmagazine.com/cattle-industry-structure/best-measure-ranch-sustainability-economic-profit ability

Mishra, A. K., El-Osta, H. S., \& Steele, C. J. (1999). Factors Affecting the Profitability of Limited Resource and Other Small Farms. Agricultural Finance Review, 59.

Mishra, A., Wilson, C., \& Williams, R. (2009). Factors affecting financial performance of new and beginning farmers. Agricultural Finance Review, 69(2), 160-179. https://doi.org/10.1108/00021460910978661

Mzyece, A. (2016). Effect of Buyer Type on Market Participation of Smallholder Farmers [Kansas State University]. Retrieved from http://krex.k-state.edu/dspace/handle/2097/32945

Olwande, J., Smale, M., Mathenge, M. K., Place, F., \& Mithöfer, D. (2015). Agricultural marketing by smallholders in Kenya: A comparison of maize, kale and dairy. https://doi.org/10.1016/j.foodpol.2015.02.002

Omiti, J. M., Otieno, D. J., Nyanamba, T. O., \& Mccullough, E. (2009). Factors influencing the intensity of market participation by smallholder farmers : A case study of rural and peri-urban areas of Kenya. African Journal of Agricultural and Resource Economics, 3(1), 57-82.

Savannah Accelerated Development Authority. (2010). Savannah Accelerated Development Authority Strategy and Work Plan.

Singh, I., Squire, L., \& Strauss, J. (1985). Agricultural Household Models: Extensions, Applications, and Policy. John Hopkins University Press.

Tackie, N., Findlay, H., \& Baharanyi, N. (1998). Farm Products Marketing Practices by Limited Resource Farmers. Journal of Agribusiness, 16.

Tey, Y. S., \& Brindal, M. (2015). Factors Influencing Farm Profitability. Susutainable Agriculture Reviews, 235-300. https://doi.org/10.1007/978-3-319-09132-7_5

Usaid Ghana. (2011). Feed The Future FY 2011-2015 Multi-Year Strategy - Ghana. Retrieved from http://mofa.gov.gh/site/wp-content/uploads/2014/09/USAID-FtF-Ghana-Strategy-2011-2015.pdf

Vakis, R., Sadoulet, E., de Janvry, A., \& Cafiero, C. (2004). Testing for separability in household models with heterogeneous behavior: A mixture model approach (Issue Paper 990). Retrieved from http://repositories.cdlib.org/are

Zanello, G. (2012). Mobile Phones and Radios: Effects on Transactions Costs and Market Participation for Households in Northern Ghana. Journal of Agricultural Economics, 63(3), 694-714. https://doi.org/10.1111/j.1477-9552.2012.00352.x

Zanello, G., Srinivasan, C. S., \& Shankar, B. (2014). Transaction Costs, Information Technologies, and the Choice of Marketplace among Farmers in Northern Ghana. Journal of Development Studies, 50(9), 1226-1239. https://doi.org/10.1080/00220388.2014.903244

Zereyesus, Y. A., Amanor-Boadu, V., Ross, K., \& Guvele, C. (2015). Feed the Future Ghana 2015 Zone of Influence Interim Assessment Report.

Zereyesus, Y. A., Ross, K. L., Amanor- Boadu, V., \& Dalton, T. (2014). Baseline Feed the Future Indicators for Northern Ghana 2012.

\section{Appendix A}

\section{Instrumental Variable Regression Results}

Equation (4) below is the empirical model of interest in this research. Equation (4) and (5) show the suspected simultaneity in examining the effects of quantity sold on profitability.

$$
\begin{gathered}
G M=\alpha_{0}+\alpha_{1} \text { Age }+\alpha_{2} \text { Gnd }+\alpha_{3} H H \text { siz }+\alpha_{4} \text { Lit }+\alpha_{5} \text { Fout }+\alpha_{6} \text { Qsold }+\alpha_{6} \text { Buyer } \\
\text { Qsold }=\beta_{0}+\beta_{1} \text { Age }+\beta_{2} \text { Gnd }+\beta_{3} H \text { Hsiz }+\beta_{4} \text { Lit }+\beta_{5} \text { Fout }+\beta_{6} \text { Buyer }+\beta_{6} \text { Price }+\beta_{7} \text { Info }+\beta_{8} \text { Crop }+\beta_{9} \text { Multbuyers }
\end{gathered}
$$

Where Gnd is gender, HHsiz is household size, Lit is literacy, Fout is farm output, Qsold is quantity sold and Buyer is buyer type, Info is access to information, Crop is type of crop grown and Multbuyers is the number of buyers a farmer sold to. 


\subsection{Test of Exogeneity of Quantity Sold}

To test for exogeneity of Quantity sold, we first estimate equation 5 and get the predicted values of Quantity sold $\widehat{Q s o l d}$. Then we include $\widehat{Q \text { sold }}$ as an independent variable in equation 4, estimate it and test if the coefficient on $\widehat{Q \text { sold }}$ is statistically equal to zero. Based on the results of the $\mathrm{F}$ test (Prob $>\mathrm{F}=0.8761$ ), we fail to reject the null hypothesis that the coefficient on $\widehat{Q s o l d}$ is equal to zero. Therefore, quantity sold is not endogenous in this system of equation.

Although the test for endogeneity showed that quantity sold is not endogenous, we still went ahead to run Instrument Variable (IV) regression using Two-Stage Least Squares (2SLS) and efficient Generalized Method of Moments (GMM). The reason for doing this was that if the structural form equation for quantity sold was mis-specified, then the results of the endogeneity test could be unreliable. In this case, the results of the 2SLS and efficient GMM would be very different from those of the OLS regression.

In running the IV regression, we used quantity sold in place of the crop quantity sold (maize quantity sold, rice quantity sold and soybean quantity sold) to avoid the complexity of identifying different IVs for each of the three crop quantities. We therefore lost the advantage of observing how profitability changes with quantity of each crop sold. Three possible IVs were identified for use in the IV regression. These included quantity of output given out as gifts, quantity of output stored and household hunger scale. The reasoning was that households that are able to store or gift large quantities are also likely to have large quantities to sell while households with a high hunger scale are less likely to sell large quantities.

The regression test for the relevance of three potential instrument variables (IVs) are shown in Table SM1. Based on the regression based test for relevance of IV and the correlation between the endogenous variable (quantity sold) and the IVs, we discard household hunger scale and only use quantity of output given out as gifts and quantity of output stored as suitable IVs.

Table A-1. Regression Test for Relevance of IVs

\begin{tabular}{lll}
\hline Variable & Coefficient & Standard Error \\
\hline Quantity of Gift $(\mathrm{kg})$ & $0.39^{* * *}$ & 0.13 \\
Quantity stored $(\mathrm{kg})$ & $0.09 * * *$ & 0.01 \\
Hunger scale & -28.37 & 76.11 \\
ccons & 202.26 & 98.82 \\
\hline
\end{tabular}

Note: Asterisks, $* * *=$ significant at $1 \%, * *=$ significant at $5 \%$ and $*=$ significant at $10 \%$

Table A-2. Correlation between IVs and Endogenous Variable

\begin{tabular}{ll}
\hline Variable & Quantity Sold \\
\hline Quantity Sold & 1 \\
Quantity of Gift $(\mathrm{kg})$ & 0.1932 \\
Quantity stored $(\mathrm{kg})$ & 0.3719 \\
Hunger scale & -0.0448 \\
\hline
\end{tabular}

The $\mathrm{J}$ test for specification of the IV regression using 2SLS estimation presented in Table SM3 shows that the model is correctly specified. Table SM4 shows the results of the 2SLS IV regression in which quantity sold is considered endogenous and instrumented using quantity stored and quantity given out as gifts. The results of the 2SLS regression show that quantity sold has a positive significant effect on profitability. An additional kilogram sold increases profit by 0.63 GHS. The coefficients on age and household also do not deviate very much from those in the OLS. This supports the finding that the OLS estimation may be free of endogeneity and therefore consistent and more efficient than 2SLS.

Table A-3. J Specification Test Results for IV (2SLS) Regression

\begin{tabular}{lllll}
\hline & \multicolumn{2}{l}{ Test of Over-identification restrictions } \\
\hline Model & \multicolumn{2}{l}{ Gross Margin } & \multicolumn{2}{l}{ Gross Margin per Acre } \\
Chi square Score & 1.24009 & $\mathrm{p}=0.2655$ & 6.83257 & $\mathrm{p}=0.0328$ \\
\hline
\end{tabular}


Table A-4. Results of 2SLS IV Regression

\begin{tabular}{lllll}
\hline & \multicolumn{2}{l}{ Gross Margin1 $(\mathrm{n}=292)$} & \multicolumn{2}{l}{ Gross Margin per Acre2 $(\mathrm{n}=286)$} \\
\hline Variable & Coefficient. & Robust Std. Err. & Coefficient & Robust Std Error \\
\hline Quantity Sold & $0.63^{* * *}$ & 0.18 & -0.02 & 0.17 \\
Age & $4.14^{* * *}$ & 1.26 & $4.52^{*}$ & 2.26 \\
Female & 7.77 & 122.37 & 175.79 & 172.57 \\
Household size & $-9.80^{* *}$ & 4.13 & 0.85 & 8.44 \\
Literate & $183.61 *$ & 103.18 & 52.88 & 81.45 \\
Farm Output & 0.13 & 0.22 & 0.00 & 0.05 \\
Sold to Aggregators & -225.87 & 141.00 & 356.49 & 391.80 \\
Sold to Processors & 206.69 & 212.70 & 28.30 & 69.58 \\
Sold to Others & 41.38 & 53.46 & 72.05 & 82.05 \\
cons & $-365.58^{* * *}$ & 136.19 & -237.13 & 178.08 \\
\hline
\end{tabular}

Note: Asterisks, $* * *=$ significant at $1 \%, * *=$ significant at $5 \%$ and $*=$ significant at $10 \%$

${ }^{1}$ For Gross margin per acre, the variable used is farm output and not yield

${ }^{2} \mathrm{R}$ - squared $=40.9 \%$.

${ }^{3} \mathrm{R}$ - squared $=4.0 \%$

Besides the 2SLS IV regression, we also estimate an efficient GMM regression in which quantity sold (an assumed endogenous variable) is instrumented using quantity stored and quantity given out as gifts. The $\mathbf{J}$ specification test for the efficient GMM regression (presented in Table SM5) shows that it is correctly specified. The results of the efficient GMM model are presented in SM6. The results show that the estimates from the efficient GMM model are close to those of the 2SLS and OLS regressions. The close similarity between OLS, 2SLS and efficient GMM confirm that OLS regression may indeed be free of endogeneity. We therefore proceed to use OLS regression because they are more efficient and consistent than 2SLS and efficient GMM in the absence of endogeneity.

Table A-5. J Specification Test Results for IV (GMM) Regression

\begin{tabular}{|c|c|c|}
\hline & Test of Over-identifica & ion restrictions \\
\hline Mo & Margin & Margin $\mathrm{p}$ \\
\hline Chi square Score & $.140424 \quad \mathrm{p}=0.7079$ & $p=0.4603$ \\
\hline
\end{tabular}

Table A-6. Results of GMM IV Regression

\begin{tabular}{lllll}
\hline & \multicolumn{2}{l}{ Gross Margin $^{1}(\mathrm{n}=302)$} & \multicolumn{2}{l}{ Gross Margin per Acre $^{2}(\mathrm{n}=302)$} \\
\hline Variable & Coefficient. & Robust Std. Err. & Coefficient & Robust Std Error \\
\hline Quantity Sold & $0.66^{* * *}$ & 0.17 & 0.06 & 0.14 \\
Age & $4.13^{* * *}$ & 1.26 & $3.30^{*}$ & 1.88 \\
Female & 9.38 & 121.55 & 73.21 & 135.69 \\
Household size & $-10.31^{* * *}$ & 3.95 & -2.52 & 7.59 \\
Literate & $187.06^{*}$ & 104.36 & 38.22 & 60.49 \\
Farm Output & 0.13 & 0.21 & 0.02 & 0.05 \\
Sold to Aggregators & $-249.90^{*}$ & 126.55 & 135.36 & 329.63 \\
Sold to Processors & 186.18 & 202.36 & -3.97 & 53.07 \\
Sold to Others & 38.24 & 52.52 & 43.11 & 71.73 \\
cons & $-369.82^{* * *}$ & 137.03 & -152.26 & 147.02 \\
\hline
\end{tabular}

Note: Asterisks, $* * *=$ significant at $1 \%, * *=$ significant at $5 \%$ and $*=$ significant at $10 \%$

${ }^{2} \mathrm{R}$ - squared $=40.0 \%$.

${ }^{3} \mathrm{R}$ - squared $=4.1 \%$

\section{Copyrights}

Copyright for this article is retained by the author(s), with first publication rights granted to the journal.

This is an open-access article distributed under the terms and conditions of the Creative Commons Attribution license (http://creativecommons.org/licenses/by/3.0/). 